\title{
Isolation and characterization of new fluoroacetate resistant/acetate non-utilizing mutants of Neurospora crassa
}

\author{
N. E. Owen, ${ }^{1}$ P. T. Chaure ${ }^{1}$ and I. F. ConNerton ${ }^{2 *}$ \\ ${ }^{1}$ Department of Microbiology, University of Reading, Whiteknights, P.O. Box 228, Reading RG6 $2 A J, U K$ \\ ${ }^{2}$ Protein Engineering Department, AFRC Institute of Food Research, Earley Gate, Whiteknights Road, \\ Reading RG6 $2 E F, U K$
}

(Received 14 May 1992; accepted 13 August 1992)

\begin{abstract}
Sixty-two mutants of the filamentous fungus Neurospora crassa were isolated on the basis of resistance to the antimetabolite fluoroacetate. Of these, 14 were unable to use acetate as sole carbon source (acetate non-utilizers, acu) and were the subject of further genetic and biochemical analysis. These mutants fell into four complementation groups, three of which did not complement any known acu mutants. Mutants of complementation group 3 failed to complement acu-8, demonstrated similar phenotypic properties and proved to be closely linked (less than $2 \%$ recombination) but not allelic. Representatives of groups 2 and 4 were mapped to independent loci; the single representative of group 1 could not be mapped. The four complementation groups were therefore designated as genes acu-10 to acu-13 respectively. All the mutants demonstrated normal acetate-induced expression of acetyl-CoA synthetase and the unique enzymes of the glyoxylate cycle and gluconeogenesis. The nature of these mutations is therefore quite different to those reported for other fungal species. Mutant acu-11 was unable to fix labelled acetate, indicating the loss of an initial transport function; partial enzyme lesions were observed for acu-12 (acetyl-CoA hydrolase) and acu-13 (acetate-inducible NAD ${ }^{+}$-specific malate dehydrogenase).
\end{abstract}

\section{Introduction}

Many fungi can utilize acetate as sole carbon source. In a few species acetate non-utilization has been used as a criterion for the selection of biochemical mutants, including the filamentous ascomycetes Aspergillus nidulans (Armitt et al., 1976) and Neurospora crassa (Flavell \& Fincham, 1968a), together with the basidiomycete Coprinus cinereus (Casselton \& Casselton, 1974) and the yeast Yarrowia lypolytica (Barth, 1985).

Acetate is incorporated via acetyl-CoA into the glyoxylate cycle, an anaplerotic or topping-up pathway to the TCA cycle. This involves two reactions, catalysed by the enzymes isocitrate lyase and malate synthase, which bypass the two decarboxylation steps of the TCA cycle. In addition to the enzymes of the glyoxylate cycle, three more enzymes play critical roles in acetate metabolism: phosphoenolpyruvate carboxykinase catalyses the conversion of oxalacetate to phosphoenolpyruvate, which links acetate metabolism to gluconeogenesis;

* Author for correspondence. Tel. (0734) 357000; fax (0734) 267917.

Abbreviations: DTNB, 5',5'-dithiobis(2-nitro)benzoic acid; RIP, repeat induced point (mutation). malic enzyme, which is necessary for the conversion of malate to free pyruvate as an essential precursor of amino acid synthesis; and fructose-1,6-biphosphatase, to provide a supply of hexose sugars. The enzyme NADP+. specific isocitrate dehydrogenase also has an effect on the glyoxylate cycle enzymes by competing for isocitrate and may, therefore, affect the flow of metabolites through the cycle. $\mathrm{NAD}^{+-}$and $\mathrm{NADP}^{+}$-specific malate dehydrogenases, together with glutamate oxalacetate transaminase may enable the flow of $\mathrm{NAD}^{+}$and $\mathrm{NADP}^{+}$between the glyoxysome and mitochondrion (Cioni et al.,1978).

The first mutants in the filamentous fungi with an inability to utilize acetate were those isolated on the basis of fluoroacetate resistance in Aspergillus nidulans, mapping at three distinct loci : fac $A$, deficient in acetyl-CoA synthetase $f a c B$, the regulatory mutation, and $f a c C$, of unknown function (Apirion, 1965). The $f a c B$ mutations resulted in pleiotropic enzyme deficiencies in glyoxylate cycle enzymes when induced on acetate (Apirion, 1965; Armitt et al., 1976). Two classes of phenotypic mutant were identified by Apirion (1965): $f a c\left(f a c^{+} a c u\right)$ and $f a n$ $\left(\mathrm{fac}^{+} \mathrm{acu}^{+}\right)$; the first of these has been the subject of further study. The rationale behind this selection was that fluoroacetate is converted to mitochondrial fluoro- 
citrate by acetyl-CoA synthetase and citrate synthase. Monofluorocitrate is a potent inhibitor of aconitase (Peters, 1957) and citryl-glutathione synthetase (Kun et al., 1977); therefore mutants that do not mobilize the fluoroacetate will be resistant.

Armitt et al. (1976) identified ten new acetate nonutilizing $(a c u)$ loci, in addition to the fluoroacetate resistant mutants (Armitt et al., 1976). The acuA mutants were allelic to $f a c \mathrm{~A}$ and deficient in acetyl-CoA synthetase. Mutants were also identified in the structural genes for isocitrate lyase (acuD), malate synthase (acuE), phosphoenolpyruvate carboxykinase $(a c u F)$, fructose1,6-biphosphatase $(a c u G)$ and malic enzyme (acuK and $a c u M$ ) ; however, none were equivalent to $f a c B$. These loci were not linked and occurred scattered throughout the genome.

Flavell \& Fincham (1968a) isolated numerous mutants of Neurospora crassa on the basis of their loss of ability to use acetate as sole carbon source. They fell into seven distinct complementation groups mapping to seven independent loci. Three of these groups possessed single enzyme deficiencies similar to those found in Aspergillus: $a c u-3$ and $a c u-5$ lacked isocitrate lyase and acetyl-CoA synthetase respectively, whereas acu-6 was deficient in phosphoenolpyruvate carboxykinase. Later, Rao \& Debusk (1977) reported an acetate non-utilizing permease deficient mutant and designated it $a c p^{-i}$.

Thomas et al. (1988) endeavoured to clone genes expressed during the adaptation of Neurospora from sucrose to acetate as sole carbon source. Two clones were identified by their ability to complement the $N$. crassa acetyl-CoA synthetase mutant (acu-5) and the $A$. nidulans malate synthase mutant $(a c u E)$. A third clone was used to generate a novel acu mutant, acu-8, utilizing the RIP (repeat induced point mutation) phenomenon of Neurospora (Marathe et al., 1990), and now thought to represent a null allele deficient in acetyl-CoA hydrolase (Connerton et al., 1992). Subsequently, the malate synthase deficient class was represented by RIP mutants and designated acu-9 (Connerton, 1990). RIP is a premeiotic phenomenon observed in $N$. crassa whereby duplicated sequences undergo extensive cytosine methylation and numerous GC $\rightarrow$ AT base transitions, thereby disrupting the participating sequences (Selker et al., 1987; Cambareri et al., 1989).

The current paper describes the isolation and characterization of a further four acetate non-utilizing mutants that were selected initially on the basis of fluoroacetate resistance.

\section{Methods}

Strains. The strains used in biochemical and heterokaryon tests were wild-type 74 A/a (ST $A / a) ; a c p^{-i}$ (Rao \& Debust, 1977); acu-1 (JI48); acu-3 (JI38); acu-5 (JI18; 94-78); acu-6 (JI31); acu-7 (JI36) (Flavell \&
Fincham, 1968a b); acu-8 (T27-1-8) (Marathe et al., 1990); and acu-9 (T11-1) (Connerton, 1990). Linkage group marker strains used for mapping gene loci were alcoy $[T(I ; I I) a l-1 ; T(I I I ; V I) y l o-1 ; T(I V ; V) c o t]$ (Perkins, 1964); arg-3; his-3; nic-2; al-1 (FGS5544) I; trp-3 (FGS4093) IIR; arg-10 (FGS4141) VII.

Media. Vogel's sucrose minimal medium contained $1 \%(w / v)$ Vogel's salts (Vogel, 1956) supplemented with d-biotin $\left(1 \mathrm{mg} \mathrm{l}^{-1}\right)$ with $1.5 \%$ $(w / v)$ sucrose (BDH) as carbon source. Solid medium contained $0.5 \%$ $(w / v)$ fructose and glucose (BDH) as carbon source together with $2 \%$ (w/v) L-sorbose (Sigma) for induction of colonial growth (Tatum et al., 1949). Vogel's acetate minimal medium contained sodium acetate (BDH) as sole carbon source, routinely at a final concentration of $40 \mathrm{~mm}$ (optimal for wild-type growth). Other carbon sources are detailed in the text, for which solid medium included $0.2 \%$ sorbose. Vogel's fluoroacetate medium contained sodium fluoroacetate (Aldrich/Sigma) at a final concentration of $500 \mathrm{~mm}$ supplemented with $0.5 \%$ glucose and fructose and $0.2 \%$ sorbose. All solid media contained $1.5 \%$ agar (Difco). Concentrations of other supplements were as follows: ethanol $0.5 \%(w / v)$; butyrate, glycerol and oleate, all $1 \%(w / v)$; $\mathrm{L}$-arginine, -histidine, -methionine, -tryptophan, all $1 \mathrm{mM}$; nicotinamide, $2 \mu \mathrm{g} \mathrm{ml}^{-1}$

Mutagenesis. A $5 \mathrm{ml}$ suspension of $10^{7}-10^{8}$ viable conidia $\mathrm{ml}^{-1}$ (STa) was treated with $200 \mu \mathrm{l}$ of a $1 \mathrm{mg} \mathrm{ml}^{-1}$ solution of NTG ( $N^{\prime}$-methyl- $N^{\prime}$ nitrosoguanidine, Sigma) and gently shaken at room temperature for 20 min to give $90 \%$ killing. The suspension was washed three times with $10 \mathrm{ml}$ of sterile water and resuspended in $5 \mathrm{ml}$ of sterile water; $200 \mu \mathrm{l}$ of suspension was then plated out directly onto fluoroacetate, and overlaid with $10 \mathrm{ml}$ of fresh fluoroacetate medium after $3 \mathrm{~h}$ incubation at $30^{\circ} \mathrm{C}$ before continued incubation for 3-5 d.

Growth tests. A small quantity of conidia was streaked onto plates containing the appropriate growth medium including sorbose and growth was scored (as $+/-$ ) after $3 \mathrm{~d}$ incubation at $30^{\circ} \mathrm{C}$. Growth tests on medium without sorbose were scored after $16 \mathrm{~h}$ incubation at $30^{\circ} \mathrm{C}$, except when scoring cot for which $37^{\circ} \mathrm{C}$ was used. For scoring in liquid medium, $0.05 \mathrm{ml}$ of a conidial suspension was used to inoculate $2 \mathrm{ml}$ of medium and growth scored after 2-3 d.

Crossing procedure and revival of ascospores. Sexual crosses were made on $1 \times$ Westergaard and Mitchell's crossing medium (Westergaard \& Mitchell, 1947), whether on slants with $1.5 \%$ sucrose or in Petri dishes containing discs of $3 \mathrm{MM}$ filter paper (cellulose) as carbon source to increase the fertility of crosses. Ascospores were collected from the glass or plastic surfaces after release and germinated on Vogel's sucrose medium plus the appropriate supplements after heatshock at $60^{\circ} \mathrm{C}$.

Enzyme assays. Gluconeogenic, glyoxylate cycle and acetate mobilizing enzyme were assayed together with those enzymes of the TCA cycle potentially involved in acetate utilization from wild-type and representative mutant strains. Mycelial pads were grown in Vogel's sucrose medium for $22 \mathrm{~h}$, followed by transfer to acetate medium for $6 \mathrm{~h}$ at $30^{\circ} \mathrm{C}$ with shaking. Crude enzyme extracts were then prepared by grinding the mycelial pads with chilled $0 \cdot 1 \mathrm{M}$-sodium phosphate buffer (pH 7.2) and acid washed sand. Supernatants were retrieved after centrifugation at $6000 \mathrm{~g}$ for $3 \mathrm{~min}$ in a microcentrifuge and stored on ice for use in enzyme assays and protein determinations.

Isocitrate lyase (EC 4.1.3.1). Assayed as described by Dixon \& Kornberg (1959). The assay mixture contained $0.1 \mathrm{M}$-sodium phosphate buffer, $\mathrm{pH} 7 \cdot 2,10 \mathrm{mM}-\mathrm{MgCl}_{2}$ and the reaction was initiated by addition of $12.5 \mathrm{~mm}$-DL-isocitric acid at $30^{\circ} \mathrm{C}$. The reaction was monitored at $324 \mathrm{~nm}$ for conversion of $0.1 \mathrm{M}$-phenylhydrazine. $\mathrm{HCl}$ to glyoxylatephenylhydrazone.

Acetyl-CoA synthetase (EC 6.2.1.1). Assayed as described by Jones \& Lipman (1959) with modifications available from Sigma, coupling hydroxylamine to acetyl-CoA formation. The colour reaction was 
developed using acid ferric chloride and measured at $546 \mathrm{~nm}$ against a reagent blank.

Malate synthase (EC 4.1.3.2). Assayed as described by Dixon \& Kornberg (1959). The reaction mixture contained $0.1 \mathrm{M}$-sodium phosphate buffer, $10 \mathrm{mM}-\mathrm{MgCl}_{2}, 0.02 \mathrm{mM}$-acetyl-CoA and $0.1 \mathrm{ml}$ of enzyme extract, and the reaction was initiated by addition of $5 \mathrm{~mm}$ glyoxylate after an initial $3 \mathrm{~min}$ incubation at $30^{\circ} \mathrm{C}$; the disappearance of acetyl-CoA was monitored at $232 \mathrm{~nm}$. Alternatively, the reaction was stopped by addition of $0.5 \mu \mathrm{mol} 5,5^{\prime}$-dithiobis(2-nitro)benzoic acid (DTNB), which reacts with free CoA-SH. The increase in absorbance of the yellow product was measured at $412 \mathrm{~nm}$.

Phosphoenolpyruvate carboxykinase (EC 4.1.1.32). The reaction

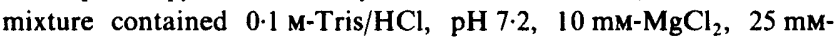
$\mathrm{KHCO}_{3}, 1 \mathrm{~mm}$-ADP, $2.5 \mathrm{~mm}$-NADH, $15 \mathrm{~mm}$-phosphoenolpyruvate and $0.05 \mathrm{ml}$ of enzyme extract. The reaction was initiated by addition of phosphoenolpyruvate after $2-3 \mathrm{~min}$ incubation at $30^{\circ} \mathrm{C}$ and the oxidation of NADH was monitored at $340 \mathrm{~nm}$ in the presence of excess endogenous malate dehydrogenase.

$N A D P^{+}$-specific malic enzyme $(E C$ 1.1.1.40). The reaction mixture constained $0.75 \mathrm{ml} \quad 0.1 \mathrm{M}-\mathrm{Tris} / \mathrm{HCl}, \mathrm{pH} 7.2,0.1 \mathrm{ml} \quad 0.1 \mathrm{M}-\mathrm{MgCl}_{2}$, $0.05 \mathrm{ml} 1 \mathrm{~mm}$-dithiothreitol (DTT), $0.01 \mathrm{ml} 25 \mathrm{~mm}$-NADP ${ }^{+}, 0.05 \mathrm{ml}$ $1 \mathrm{M}$-malate and $0.05 \mathrm{ml}$ of enzyme extract in $1 \mathrm{mM}$-DTT. The formation of pyruvate was followed after $5 \mathrm{~min}$ reaction time by colour development with $0.5 \mathrm{ml} \mathrm{0.1 \% 2,4-dinitrophenylhydrazine} \mathrm{in} 2 \mathrm{M}-\mathrm{HCl}$.

Glutamate:oxaloacetate transaminase (EC 2.6.1.15). The reaction mixture contained $0.8 \mathrm{ml} 300 \mathrm{~mm}$-sodium phosphate buffer, $\mathrm{pH} 7.4$, $0.05 \mathrm{ml} 5 \mathrm{~mm}$-NADH, $0.1 \mathrm{ml} 180 \mathrm{~mm}$-2-oxoglutarate and $0.05 \mathrm{ml}$ of enzyme extract. The reaction was initiated by addition of aspartate at $30^{\circ} \mathrm{C}$ and the disappearance of NADH was measured at $340 \mathrm{~nm}$.

$N A D^{+}$-specific malate dehydrogenase (EC 1.1.1.37). The reaction mixture contained $0.84 \mathrm{ml} 300 \mathrm{~mm}$-sodium phosphate buffer, $\mathrm{pH} 7 \cdot 4$, $0.05 \mathrm{ml} 5 \mathrm{~mm}-\mathrm{NADH}, 0.01 \mathrm{ml} 250 \mathrm{~mm}$-oxalacetate and $0.05 \mathrm{ml}$ of diluted enzyme extract. Due to the excess of $\mathrm{NAD}^{+}$-specific malate dehydrogenase in the extract, it was necessary to dilute the extract $1 / 50$ in phosphate buffer. The reaction was initiated by addition of oxalacetate at $30^{\circ} \mathrm{C}$. The disappearance of NADH was measured at $340 \mathrm{~nm}$. Activity gels were run using $10 \%(\mathrm{w} / \mathrm{v})$ polyacrylamide gels in a continuous buffer system containing $0.05 \mathrm{M}$-Tris $/ 0.38 \mathrm{M}$-glycine, pH 8.9, with cell-free extracts. Isoenzymes were stained using $0.05 \mathrm{M}$ Tris/ $\mathrm{HCl}, \mathrm{pH} 8.9,0.16 \% \mathrm{NAD}^{+}, 0.0016 \%$ phenazine ethosulphate, $0.045 \%$ nitrotetrazolium blue and $0.2 \mathrm{M}$-DL-malate for $20 \mathrm{~min}$ in the dark.

$N A D P^{+}$-specific malate dehydrogenase (EC 1.1.1.82). The reaction

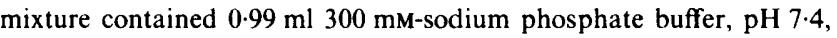
$0.01 \mathrm{ml} 25 \mathrm{~mm}-\mathrm{NADP}^{+}, 0.05 \mathrm{ml} 1 \mathrm{M}$-malate and $0.05 \mathrm{ml}$ of enzyme extract. The reaction was initiated by addition of malate at $30^{\circ} \mathrm{C}$. The formation of NADPH was measured at $340 \mathrm{~nm}$.

$N A D^{+}$-specific isocitrate dehydrogenase (EC 1.1.1.41). The reaction mixture consisted of $0.83 \mathrm{ml}$ of $250 \mathrm{mM}$-sodium phosphate buffer, pH 7.2, $0.01 \mathrm{ml} 25 \mathrm{~mm}-\mathrm{NAD}^{+}, 0.1 \mathrm{ml} 0.1 \mathrm{M}-\mathrm{MgCl}_{2}, 0.05 \mathrm{ml} 500 \mathrm{~mm}-$ DL-isocitrate and $0.01 \mathrm{ml}$ of enzyme extract. The appearance of NADH was followed at $340 \mathrm{~nm}$.

$N A D P^{+}$-specific isocitrate dehydrogenase (EC 1.1.1.42). The reaction mixture was essentially similar to that for $\mathrm{NAD}^{+}$-specific isocitrate dehydrogenase except that $25 \mathrm{~mm}-\mathrm{NADP}^{+}$replaced $\mathrm{NAD}^{+}$and the reaction was followed as the appearance of NADPH.

Acetyl-CoA hydrolase (EC 3.1.2.1). Acetyl-CoA hydrolase was assayed in post-organellar fractions (extracted in $0.4 \mathrm{M}$-sucrose, $10 \mathrm{~mm}$ Tricine, $\mathrm{pH}$ 7.2) by measuring the appearance of free CoA-SH using DTNB (Connerton et al., 1992). The assay mixture contained $0.8 \mathrm{ml}$ $50 \mathrm{~mm}$-Tris/HCl, pH 7.5, $0.1 \mathrm{ml} 2 \mathrm{~mm}$-acetyl-CoA and $0.1 \mathrm{ml}$ of and was incubated at $30^{\circ} \mathrm{C}$ for $10 \mathrm{~min}$ before termination and colour development with $0.5 \mu \mathrm{mol}$ DTNB.

$\left[{ }^{14} \mathrm{C}\right]$ Acetate uptake. A suspension of $10^{6}$ conidia in $25 \mathrm{ml}$ of Vogel's minimal medium containing $40 \mathrm{mM}-\left[{ }^{14} \mathrm{C}\right]$ acetate $\left[0.2 \mu \mathrm{Ci} \mathrm{m} l^{-1}\right.$ $\left.\left(7.4 \mathrm{kbq} \mathrm{ml}^{-1}\right)\right]$ was incubated at $30^{\circ} \mathrm{C}$, stirring gently and shaking; samples $(2 \mathrm{ml})$ were removed at $2 \mathrm{~min}$ intervals for $16 \mathrm{~min}$. These samples were washed on a Millipore membrane filter (pore size $22 \mu \mathrm{m}$ ) with $10 \mathrm{ml}$ of Vogel's minimal medium before drying at $65^{\circ} \mathrm{C}$ for $1 \mathrm{~h}$ and scintillation counting against known standards.

Estimation of protein concentration. The concentration of protein in the enzyme extracts was determined using the Coomassie blue G-250 based protein assay reagent (Pierce). 'Ready to use' reagent $(200 \mu \mathrm{l})$ was added to a well in a 96-well microtitre tray together with $5 \mu \mathrm{l}$ bovine serum albumin (Sigma) ranging from $0.25-1.5 \mathrm{mg} \mathrm{ml}^{-1}$. A suitable dilution of enzyme extract $(5 \mu \mathrm{l})$ was added in separate wells. The protein concentration was determined at $720 \mathrm{~nm}$ (filter 7) using the Titertek Multiskan MCC system.

\section{Results}

\section{Selection and isolation of mutants}

A concentration of sodium fluoroacetate that inhibited growth of the wild-type strains (ST $A / a$ ), but supported growth of acu-8 (Marathe et al., 1990), which was found to be fluoroacetate resistant, was determined in preliminary plate assays. A sandwich technique similar to that adopted by Apirion (1965) was used in the selection procedure. Conidial suspension (100-200 $\mu \mathrm{l})$ at approximately $10^{6}$ viable conidia $\mathrm{ml}^{-1}$ was plated directly onto various concentrations of Vogel's fluoroacetate medium. After $3-4 \mathrm{~h}$ incubation at $30^{\circ} \mathrm{C}$, the germinating spores were overlaid with fresh medium. Resistant colonies appeared after 3-4 d. Neurospora proved to be surprisingly tolerant to fluoroacetate: growth of ST $A / a$ was inhibited completely only at $0.4 \mathrm{M}$, whereas $a c u-8$ continued to grow well up to $0.5 \mathrm{M}$-fluoroacetate.

Of $10^{6}$ conidia screened in a series of isolation experiments, 62 vigorously growing fluoroacetate resistant colonies were selected; of these, eight were initially discarded due to poor growth on transfer to Vogel's sucrose medium. Conidial stocks from these were scored for growth on solid Vogel's acetate medium. Fourteen isolates were acetate non-utilizing mutants $\left(\mathrm{fac}^{+} \mathrm{acu}\right)$, the majority $\left(\mathrm{fac}^{+} a c u^{+}\right)$fell into the fan class described by Apirion (1965). This second class was not examined further.

\section{Genetic analysis of the fac ${ }^{+}$acu mutants}

On the basis of growth tests with heterokaryotic conidia on liquid acetate medium, the mutants tested were arranged into four provisional complementation groups (Fig. 1). Each of these was considered to contain alleles of a single gene. No allelic complementation was 


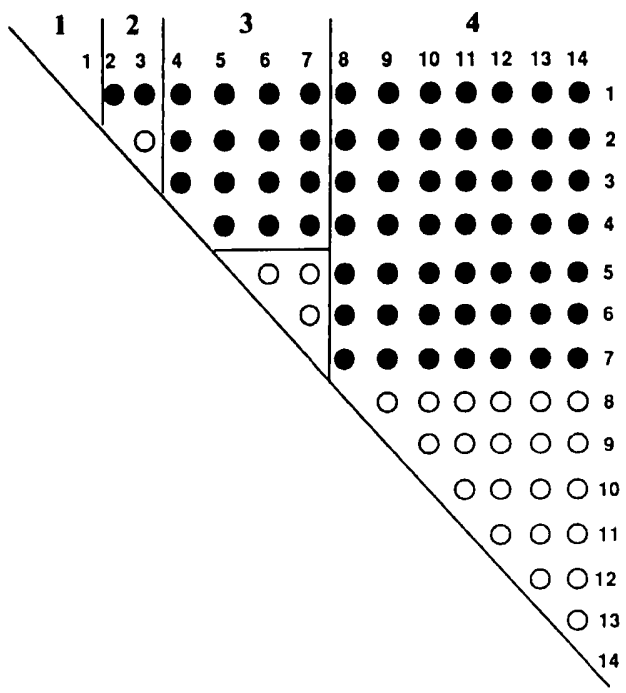

Fig. 1. Complementation analysis of $\mathrm{fac}^{+} \mathrm{acu}$ mutants. The mutants have been arranged into four groups on the basis of their ability to complement each other in heterokaryons. Numbers $1-14$ were isolated as S10-3, S30-12, S40-4, S10-4, S10-6, S10-1 1, S10-14, S10-2, S10-8, S10$15, S 10-16, S 20-1, S 30-2$ and $S 30-9$ respectively. Complementation; $O$, no complementation.

observed. A linear complementation matrix was also performed with the known acu mutants. Apart from S104 (phenotypically the tightest representative of complementation group 3), which showed no complementation with $a c u-8$, the three remaining groups complemented all available $a c u$ mutants.

Representatives from each complementation group exhibiting tight $\mathrm{Acu}^{-}$phenotypes were back-crossed twice to wild-type of the opposite mating type (ST $A$ ) to ensure that the $\mathrm{Acu}^{-}$phenotype was not due to mutation at multiple loci. Twenty ascospores from each cross to the wild-type strain were screened for their ability to utilize acetate. The ratio of $a c u^{+} / a c u$ was approximately $1: 1$ for three out of the four representatives. However, a chance observation on the growth characteristics of the mutant S10-3 after crossing to the wild-type (Fig. 1, complementation group 1) revealed a possible double mutant. The absolute ratio of $a c u^{+} / a c u$, as opposed to those ascospore progeny which grew weakly on acetate, from random ascospores was approximately $3: 1$ (27:13), implying that only the double mutant expressed the stringent phenotype. Further growth analysis revealed the second mutation to be unstable as four strains of the phenotype $\mathrm{Acu}^{+} \mathrm{Alc}^{-}$(alcohol) were identified within the acetate utilizing ascospore progeny (27). The weak $\mathrm{Acu}^{-}$phenotype was subsequently re-isolated from a third backcross to be mapped. Cultures re-isolated from backcrosses to wild-type that continued to exhibit a tight $\mathrm{Acu}^{-}$phenotype were crossed to the triple translocated strain alcoy (Perkins, 1964), bearing the visible markers albino (white conidia), cot-1 (temperature-sensitive colonial growth) and $y l o$ (yellow conidia which are epistatic to white). Representative strains S30-12 (group 2), S10-4 (group 3) and S30-9 (group 4) yielded abundant ascospore progeny from which 100 random ascospores were picked onto Vogel's sucrose minimal medium and scored for their visible markers and acetate utilization. However, the single representative of complementation group 1 (S10-3) did not produce a fertile cross with any of its derivative $a c u$ progeny. It is possible that this strain, which was originally isolated in conjunction with a second mutation, may have undergone some rearrangement and it remains unmapped.

Clear linkage was observed for \$30-9 with albino indicating either linkage group I or II. Linkage to LGII was confirmed by crossing to the trp-3 marker of LGII $(22.7 \%)$ and albino of LGI (linkage data detailed in Table 1). No linkage was apparent for S30-12 or S10-4, which indicated preliminary assignment to linkage group VII, the only linkage group not involved in the interchange present in alcoy. Strains of S30-12 and S10-4 were then crossed to arg-10 on LGVII. S30-12 demonstrated linkage to $\arg -10(21 \%)$. However, S10-4 (complementation group 3), which initially showed no complementation with $a c u-8$, demonstrated no linkage to $\arg -10$ on LGVII. As acu-8 was mapped to the distal end of the right arm of linkage group II (Marathe et al., 1990), and if S10-4 was allelic, it would not necessarily have shown linkage to alcoy. S10-4 was subsequently crossed to trp-3 on linkage group II to determine linkage and was found to be linked to $\operatorname{trp}-3(24 \%)$, but not as closely as acu- 8 $(7.8 \%)$. Crossing of S10-4 to $a c u-8$ resulted in only four $a c u^{+}$progeny of 405 tested, implying the mutations are not allelic but closely linked $(<2 \%)$. To undertake these crosses was laborious as the strains did not prove to be a particularly fertile combination. This was the case regardless of which mating-type was employed or which mutant constituted the female parent. Whether due to the interaction of their phenotypes or to the genetic mishaps that have befallen them, these mutants, in addition to producing fairly infertile crosses, also suffered from low ascospore viability. These phenomena had been noted earlier with the $a c u$ mutants of Flavell \& Fincham (1968a), although these problems were not encountered with Aspergillus (Armitt et al., 1976).

Based upon these relationships the new mutant classes were designated acu-10 (S10-3 complementation group 1), acu-11 (S30-12 and S40-4 of complementation group 2), acu-12 (S10-4 and the rest of complementation group 3) and acu-13 (S30-9 and the rest of complementation group 4).

\section{Growth characteristics of the fac mutants}

The fac mutants were tested for their growth responses on various carbon sources in liquid medium, except for 
Table 1. Linkage group analysis of progeny from crosses between fac ${ }^{+}$acu mutants and known genetic markers

\begin{tabular}{|c|c|c|c|c|}
\hline Cross & $\begin{array}{l}\text { Linkage group } \\
\text { of marker }\end{array}$ & $\begin{array}{l}\text { Progeny } \\
\text { genotypes }\end{array}$ & No. observed & $\begin{array}{l}\text { Conclusions (percentage recombination between } \\
\qquad f a c^{+} a c u \text { locus and marker) }\end{array}$ \\
\hline $\mathrm{S} 30-9 \times t r p-3$ & IIR & $\begin{array}{l}a c u+ \\
+ \text { trp-3 } \\
+\quad+ \\
\text { acu trp-3 }\end{array}$ & $\begin{array}{r}40 \\
11 \\
14 \\
1\end{array}$ & S30-9 acu linked to $\operatorname{trp}-3(22.7 \%)$ \\
\hline S30-9 $\times$ al-1 & I & $\begin{array}{l}a c u+ \\
+a l-1 \\
+\quad+ \\
\text { acu al-1 }\end{array}$ & $\begin{array}{l}35 \\
26 \\
42 \\
18\end{array}$ & S30-9 acu and $a l$ not linked $(49 \cdot 6 \%)$ \\
\hline $\mathrm{S} 10-4 \times$ arg- 10 & VIIR & $\begin{array}{l}\text { acu }+ \\
+ \text { arg-10 } \\
++ \\
\text { acu arg-10 }\end{array}$ & $\begin{array}{l}19 \\
24 \\
22 \\
17\end{array}$ & S10-4 acu and arg-10 not linked (47.5\%) \\
\hline S10-4 $\times$ trp-3 & IIR & $\begin{array}{l}a c u+ \\
+ \text { trp-3 } \\
+\quad+ \\
\text { acu trp-3 }\end{array}$ & $\begin{array}{r}31 \\
19 \\
9 \\
7\end{array}$ & S10-4 acu linked to $\operatorname{trp}-3(24 \%)$ \\
\hline $\mathrm{S} 30-12 \times \arg -10$ & VIIR & $\begin{array}{l}\text { acu }+ \\
+ \text { arg-10 } \\
+\quad+ \\
\text { acu arg-10 }\end{array}$ & $\begin{array}{r}28 \\
20 \\
10 \\
3\end{array}$ & S30-12 acu linked to $\arg -10(21 \%)$ \\
\hline
\end{tabular}

Table 2. Growth characteristics of fac mutants in Neurospora crassa

Growth responses of the mutants on various carbon sources are shown in comparison with growth of wild-type on hexose $(+++)$. No growth is indicated by - , and increasingly better growth as $(+),+,++,++$, NT, Not tested.

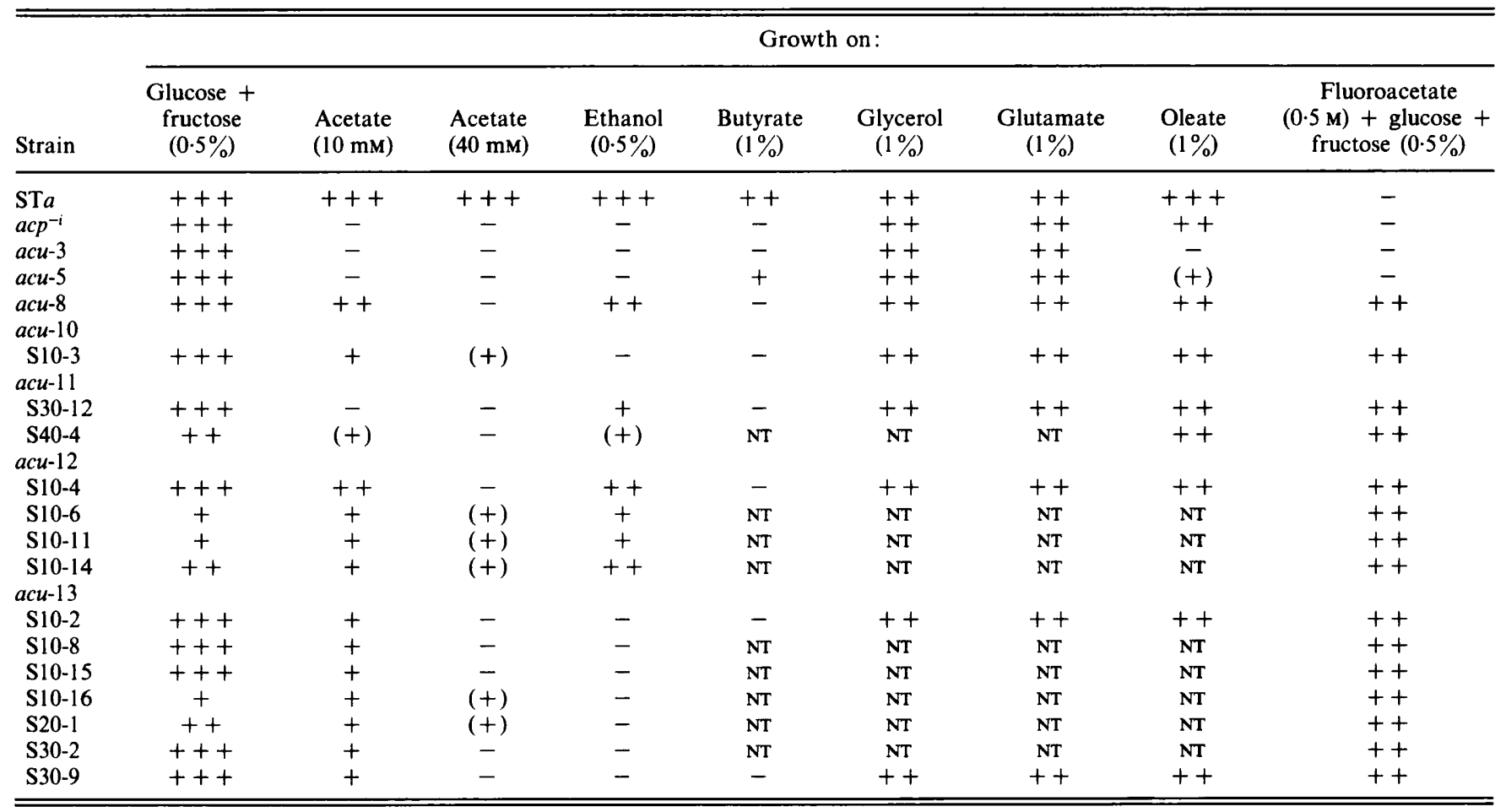

fluoroacetate where solid agar plates were used (Table 2). Generally mutants within the same complementation group showed similar growth characteristics. Of the established $a c u$ mutants only $a c u-8$ demonstrated fluoroacetate resistance. Perhaps surprisingly the acetyl-CoA synthetase deficient class (acu-5) were sensitive to fluoroacetate; in Aspergillus nidulans this is the most abundant fluoroacetate resistant class as these mutants fail to mobilize fluoroacetyl-CoA in lethal synthesis. Unusually, alleles of $a c u-11$ and $a c u-12$ showed growth on 
ethanol unlike many other known acu mutants, the notable exception being $a c u-8$. The mutants $a c u-8$ and acu-12 (S10-4) have been shown to be closely linked and demonstrate quite similar properties: $a c u-8$ is fluoroacetate resistant like S10-4; acu-8 does not complement S104 in heterokaryons; both have similar curious growth phenotypes, showing no growth on $40 \mathrm{~mm}$-acetate, but growth on $10 \mathrm{~mm}$-acetate and $0.5 \%$ ethanol (Table 2). At the standard $\mathrm{pH}$ of 5.2 for acetate medium, acu-11 (S3012) did not grow on either concentration of acetate.

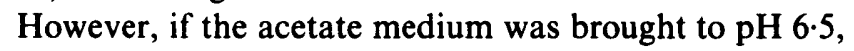
$a c u-11$ produced appreciable growth. The mutant was not generally acid sensitive, only in respect of growth on acetate.

None of the fluoroacetate resistant mutants were capable of growth on butyrate; the acetyl-CoA synthetase deficient class $(a c u-5)$ were the only acetate nonutilizers capable of this. Growth responses on oleate were also tested since oleate has been shown to induce the enzymes related to $\beta$-oxidation and has a profound influence on the ultrastructural content of cells inducing microbody formation (Kionka \& Kunau, 1985). All the $\mathrm{fac}^{+} \mathrm{acu}$ mutants showed growth on oleate; notably, only acu-3 (deficient in isocitrate lyase) completely failed to grow. Presumably the glyoxylate cycle is required for growth on oleate but acetyl-CoA synthetase (acu-5) can be bypassed.

\section{Biochemical properties of the fac mutant}

Representatives from each complementation group were assayed for the presence of enzymes of the glyoxylate cycle, gluconeogenesis and those enabling acetate metabolite mobilization (Table 3). Despite lesions in acetylCoA synthetase leading to the majority of fluoroacetate resistant strains in other fungal species, all the mutants isolated in this study demonstrated inducible levels of the enzyme. Acetyl-CoA hydrolase is thought to modulate the cytosolic levels of acetyl-CoA, and a deficiency gives rise to the fluoroacetate resistant mutant $a c u-8$ (Connerton et al., 1992). The enzyme was found to be inducible in all mutants. However, acu-12 (S10-4 and other alleles not presented), which bears some similar phenotypic properties to $a c u-8$, produced particularly low levels of the enzyme.

None of the mutants showed a deficiency in glyoxylate cycle enzymes, although acu-10 (S10-3) demonstrated significantly more isocitrate lyase activity on sucrose than did the wild-type. During growth on acetate, the enzymes of the glyoxylate cycle are located in a specialized organelle, the glyoxysome, which is a representative of a subclass of microbodies found in Neurospora (Schwitzguebel et al., 1981; Kionka \& Kunau, 1985). We have also undertaken crude fractiona- tion of these organelles (as necessary for the acetyl-CoA hydrolase assay) and found that all the mutants had intact glyoxysomes with their relative isocitrate lyase and malate synthase levels similar to wild-type. The mutants are apparently not deficient in organelle biogenesis or protein targeting.

The gluconeogenic enzymes fructose-1,6-biphosphatase and phosphoenolpyruvate carboxykinase, are induced non-coordinately with the glyoxylate cycle enzymes during growth on acetate (Beever, 1975). In all the mutant classes the two enzyme activities behaved as they do in the wild-type. The specific activity of NADP+linked malic enzyme, which generates pyruvate from malate, declined in the mutants and the wild-type upon transfer to acetate. This was perhaps unexpected as in Aspergillus nidulans the enzyme is apparently derepressed and has been ascribed an anaplerotic function in the supply of pyruvate under conditions where pyruvate kinase activity is low (McCullough \& Roberts, 1974; Kelly \& Hynes, 1981). Unusually, a NADP ${ }^{+}$-specific malate dehydrogenase activity was also detected. This enzyme became derepressed on acetate in the majority of strains, the mutant acu-11 (S30-12) being exceptional in that it showed a marked derepression on sucrose. The assay conditions for the malic enzyme and NADP+ dependent malate dehydrogenase were quite similar; therefore the reduction of $\mathrm{NADP}^{+}$may represent a compound activity. However, malic enzyme activity was also followed as the formation of pyruvate in this study, and as these enzyme activities appeared to decline and derepress in an antiparallel fashion, the malate dehydrogenase fraction may be distinguished.

In addition to derepression of $\mathrm{NADP}^{+}$-specific malate dehydrogenase on sucrose mutant acu-11 (S30-12) also showed a lower level of the $\mathrm{NAD}^{+}$-specific enzyme on acetate. However, mutant $a c u-13$ (S30-9) failed to induce $\mathrm{NAD}^{+}$-specific malate dehydrogenase activity with acetate. This mutant was investigated further by the separation and visualization of malate dehydrogenase activities on $10 \%$ native polyacrylamide gels. The wildtype and all other mutant classes produced three isoenzymic activities, only one of which (the slowest migrating band) was significantly expressed on sucrose. The middle and fastest migrating bands became plainly visible only after acetate (or ethanol) induction (Fig. 2). In contrast, $a c u-13$ (S30-9) was deficient in activity of the middle band despite some derepression of the faster migrating band. Other alleles of $a c u-13$, the most represented $\mathrm{fac}^{+} \mathrm{acu}$ class, were also either reduced or deficient in this middle band.

The wild-type and all classes of mutant had inducible levels of glutamate:oxalacetate transaminase and $\mathrm{NADP}^{+}$-specific isocitrate dehydrogenase; the $\mathrm{NAD}^{+}$dependent enzyme remained constitutive. 


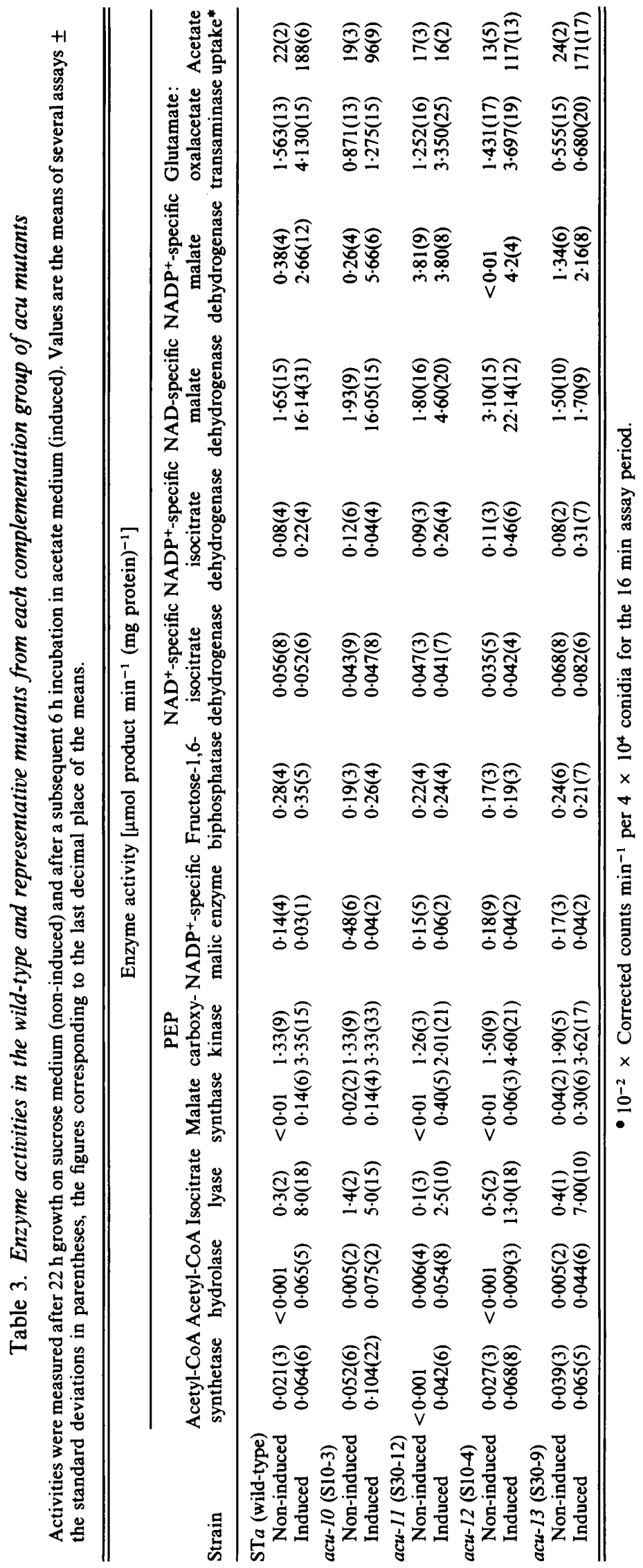




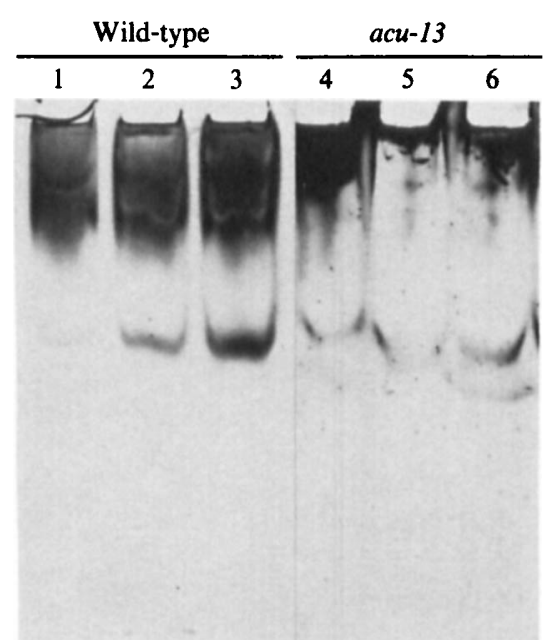

Fig. 2. Native $(10 \%)$ PAGE of crude enzyme extract, activity stained for $\mathrm{NAD}^{+}$-specific malate dehydrogenase. Lanes 1-3 and 4-6 represent wild-type (ST $A$ ) and $a c u-13$ (S30-9) activities respectively. Lanes 1 and 4 show activities after primary growth on sucrose $(16 \mathrm{~h})$, lanes 2 and 5 after subsequent transfer to ethanol $(6 \mathrm{~h})$ and lanes 3 and 6 after transfer to acetate $(6 \mathrm{~h})$.

Uptake experiments using $\left[{ }^{14} \mathrm{C}\right]$ acetate demonstrated that acu-11 (S30-12) was unable to accumulate acetate. The other classes of mutant showed near wild-type levels of $\left[{ }^{14} \mathrm{C}\right]$ acetate accumulation over the $16 \mathrm{~min}$ assay period. The lack of uptake by acu-11 (S30-12) could indicate a permease deficiency; however, it may equally reflect the inability of the mutant to metabolize and fix the labelled acetate. When uptake was assayed with shorter intervals $(30 \mathrm{~s})$, the initial rate of uptake was similar to wild-type. The substrate, however, was not retained to be fixed by metabolism. The primary destination of the acetate is potentially aberrant.

\section{Discussion}

Selection for mutants on the basis of fluoroacetate resistance resulted in the generation of four novel acu mutants, which may help to complete our understanding of the function and regulation of proteins involved in acetate metabolism in Neurospora. However, our study failed in its original aim to generate a pleiotropic mutant similar to facB found in Aspergillus nidulans (Apirion, 1965; Armitt et al., 1976; Hynes, 1977; Hynes \& Kelly 1977; Katz \& Hynes, 1989). In the yeast Yarrowia lipolytica, however, the recently isolated trans-dominant GPR-1 mutant deficient in glyoxylate pathway regulation was found not to be fluoroacetate resistant (Kujau et al., 1991). A putative facB-type mutant generated in this laboratory by duplication induced mutation was also fluoroacetate sensitive (N. E. Owen \& I. F. Connerton, unpublished data). The fac mutants of $N$. crassa selected here were initially chosen due to their vigorous growth and good condition, which may be reliant on a functional glyoxylate cycle, since there is an increase in isocitrate lyase at this stage in the vegetative life cycle of Neurospora (Turian \& Matikian, 1966). Therefore, there may have inadvertently been a selection against certain types of acu mutants. In Aspergillus, the major class of fluoroacetate resistant mutations are the fac $A$ mutations deficient in acetyl-CoA synthetase; this class was not selected in our study. Oddly, the equivalent acetyl-CoA synthetase deficient class (acu-5) of Neurospora was not fluoroacetate resistant. In the basidiomycete Coprinus cinereus, fluoroacetate selection yielded mutations at only one locus, acu-1 (Casselton \& Casselton, 1974; BaptistaFerreira \& Casselton, 1983), which results in a deficiency in acetyl-CoA synthetase. Revertants of these mutations were isolated which conferred a temperature-sensitive enzyme phenotype (Vousden \& Casselton, 1983). It was assumed that $a c u-1$ represented the structural gene for acetyl-CoA synthetase. However, the gene has recently been cloned by hybridization to the $N$. crassa and $A$. nidulans genes (Connerton et al., 1990) and found not to complement $a c u-1$; it appears that $a c u-1$ may be a regulatory mutation equivalent to $f a c B$ in Aspergillus (Maconochie et al., 1992). The variation in the mutant types observed may reflect physiological differences in the enzymes and the regulation to which they are subject, which will ultimately determine the sites of action of fluoroacetate and its adducts.

The $a c u-8$ and $a c u-12$ mutations result in similar growth properties, do not complement each other in heterokaryons and are affected in acetyl-CoA hydrolase. The mutations are closely linked on LGIIR $(<2 \%)$, which even so suggests they are independent genes. It should be noted, however, that $a c u-8$ is a RIP derived mutation and the influence, if any, of the severe changes associated with this are unknown for closely linked genetic crosses. It is formally possible that the genes encode separate subunits of the same enzyme complex that may undergo interference. In Saccharomyces cerevisiae, however, the enzyme is composed of a single polypeptide chain (Lee et al., 1989).

Mutant acu-11 (S30-12) is unable to grow on acetate but is capable of slow growth on ethanol. As there is no other known way to utilize ethanol other than via acetate it must be assumed the strain is metabolically competent. Initially, a defect in an acetate permease was indicated, which would explain the phenotype. However, as the glyoxylate cycle enzymes induced as normal and initial uptake was found to be as wild-type, the lesion is probably not a permease but concerns an internal transport problem that is apparently acid $\mathrm{pH}$ sensitive. The low levels of $\mathrm{NAD}^{+}$-specific malate dehydrogenase found in this mutant may also be due to a reduction/ 
absence of a secondary metabolite required for full induction. The acetate permease mutant $a c p^{-i}$ (Rao \& Debusk, 1977) is also likely to carry a lesion other than in the permease, since it fails to grow on ethanol and is also sensitive to fluoroacetate. Thomas \& Baxter (1987) found that this mutant did not undergo significant flux via the glyoxylate cycle when fed with $\left[{ }^{13} \mathrm{C}\right]$ acetate and examined by nuclear magnetic resonance.

Lesions resulting in non-functional structural proteins essential for the integrity of the glyoxysome might yield an $\mathrm{Acu}^{-}$phenotype, although peroxisome-less mutants isolated in the yeasts Saccharomyces cerevisiae and Hansenula polymorpha do not exhibit a specific $\mathrm{Acu}^{-}$ phenotype; rather, they are affected in fatty acid metabolism dependent upon $\beta$-oxidation (Erdmann et al., 1989; Cregg et al., 1990). All four Neurospora mutants tested, corresponding to each of the complementation groups, produced intact glyoxysomes, containing normal complements of the enzymes isocitrate lyase and malate synthase.

The mutant acu-13 (S30-9) did not induce $\mathrm{NAD}^{+}$ specific malate dehydrogenase and also had low levels of $\mathrm{NADP}^{+}$-specific malate dehydrogenase. Neurospora has three isoenzymic activities for $\mathrm{NAD}^{+}$-specific malate dehydrogenase that can be observed on activity gels, the two fastest migrating of which are induced upon transfer to acetate. Analysis of all the separate alleles of $a c u-13$ demonstrated either the loss or a reduction in intensity of the middle band upon transfer to acetate. At this stage it is not certain whether $a c u-13$ represents the structural gene for an acetate-inducible malate dehydrogenase or is pleiotropic to its induction. K. D. Munkres and colleagues have isolated mutants falling into two complementation groups ( $m a-1$ and $m a-2)$, deficient in malate utilization in the presence of the suc (ace-6) mutation (deficient in pyruvate carboxylase and requiring TCA cycle intermediates for growth) that are altered in $\mathrm{NAD}^{+}$-specific malate dehydrogenase (Munkres et al., 1965; Munkres \& Richards, 1965). These mutations are thought to reside on either LGIII or LGVII, whereas acu-13 is located on LGII. The acetate-inducible malate dehydrogenase has been located to the glyoxysome by Kobr et al. (1969), and Munkres et al. (1970) suggested that these isoenzymes may have subunits in common with those of the mitochondrial enzyme, which are altered in $m a-1$ and $m a-2$. Further information as to the nature of these isoenzymes may become available shortly as we have recently cloned at least one malate dehydrogenase structural gene from $N$. crassa (P. T. Chaure \& I. F. Connerton, unpublished).

N. E. O. was the recipient of a University of Reading research studentship and P. T. C. was the recipient of an overseas scholarship from the Indian Government.

\section{References}

APIRION, D. (1965). The two way selection of mutants and revertants in respect of acetate utilization and resistance to fluoroacetate in Aspergillus nidulans. Genetics Research 6, 317-329.

ARmitt, S., McCullough, W. \& RoberTs, C. R. (1976). Analysis of acetate non-utilizing (acu) mutants in Aspergillus nidulans. Journal of General Microbiology 92, 263-282.

Baptista-Ferreira, J. L. C. \& Casselton, L. A. (1983). An allele map of the acu-1 gene of Coprinus cinereus. Revista de Biologia 12, 187-196.

BARTH, G. (1985). Genetic regulation of isocitrate lyase in the yeast Yarrowia lipolitica. Current Genetics 10, 119-124.

BEEVER, R. E. (1975). Regulation of 2-phosphoenolpyruvate kinase and isocitrate lyase in Neurospora crassa. Journal of General Microbiology 86, 197-200.

Cambareri, E. B., Jensen, B. C., Schabtach, E. \& Selker, E. U. (1989). Repeat-induced GC $\rightarrow$ AT mutations in Neurospora. Science 244, 1571-1575.

Casselton, L. A. \& Casselton, P. J. (1974). Functional aspects of fluoroacetate resistance in Coprinus with special reference to acetylCoA synthetase deficiency. Molecular and General Genetics 132, 255264.

Cioni, M., Pinzanti, G. \& Vanni, P. (1981). Comparative biochemistry of the glyoxylate cycle. Comparative Biochemistry and Physiology $70 B, 1-26$.

Connerton, I. F. (1990). Premeiotic disruption of the Neurospora crassa malate synthase gene by native and divergent DNAs. Molecular and General Genetics 223, 319-323.

Connerton, I. F., Fincham, J. R. S., Sandeman, R. A. \& Hynes, M. J. (1990). Comparison and cross-species expression of the acetyl-CoA synthetase genes of the ascomycete fungi, Aspergillus nidulans and Neurospora crassa. Molecular Microbiology 4, 451-460.

Connerton, I. F., McCullough, W. \& Fincham, J. R. S. (1992). An acetate-sensitive mutant of Neurospora crassa deficient in acetylCoA hydrolase. Journal of General Microbiology 138, 1797-1800.

Cregg, J. M., van der Klei, I. J., Sulter, G. J, Veenhuis, M. \& HARDER, W. (1990). Peroxisome-deficient mutants of Hansenula polymorpha. Yeast 6, 87-97.

Dixon, G. H. \& Kornberg, H. L. (1959). Assay methods for key enzymes of the glyoxylate cycle. Biochemical Journal 72, 3p.

Erdmann, R. M., Veenhuis, M., Mertens, D. \& Kunau, W.-H. (1989). Isolation of peroxisome-deficient mutants of Saccharomyces cerevisiae. Proceedings of the National Academy of Sciences of the United States of America 86, 2432-2436.

Flavell, R. B. \& Fincham, J. R. S. (1968a). Acetate non-utilizing mutants of Neurospora crassa. 1. Mutant isolation, complementation studies and linkage relationships. Journal of Bacteriology 95, 10561062.

Flavell, R. B. \& Fincham, J. R. S. (1968b). Acetate non-utilizing mutants of Neurospora crassa. 2. Biochemical deficiencies and roles of certain enzymes. Journal of Bacteriology 95, 1063-1068.

HyNES, M. J. (1977). Induction of the acetamidase of Aspergillus nidulans by acetate metabolism. Journal of Bacteriology 131, 770-775.

HYNes, M. J. \& KeLly, J. M. (1977). Pleiotropic mutants of Aspergillus nidulans altered in carbon metabolism. Molecular and General Genetics 150, 193-204.

Jones, M. E. \& Lipman, F. (1955). Aceto-CoA-kinase. Methods in Enzymology 1, 585-591.

KATZ, M. E. \& HYNES, M. J. (1989). Isolation and analysis of the acetate regulatory gene $f a c B$, from Aspergillus nidulans. Molecular and Cellular Biology 12, 5696-5701.

Kelly, J. M. \& HYNES, M. J. (1981). The regulation of phosphoenolpyruvate carboxykinase and NADP-linked malic enzyme in Aspergillus nidulans. Journal of General Microbiology 123, 371-375.

KIONKA, C. \& KUNAU, W.-H. (1985). Inducible $\beta$-oxidation pathway in Neurospora crassa. Journal of Bacteriology, 161, 153-157.

Kobr, M. J., Vanderheagh, F. \& Combepine, G. (1969). Particulate enzymes of the glyoxylate cycle in Neurospora crassa. Biochemical and Biophysical Research Communications 37, 640-645.

Kujau, M., Weber, H \& Barth, G. (1992). Characterization of mutants of the yeast Yarrowia lipolytica deficient in acetyl-coenzyme A synthetase. Yeast 8, 193-203. 
Kun, E., Kirsten, E. \& Sharma, M. L. (1977). Enzymatic formation of glutathione-citryl thioester by a mitochondrial system and its inhibition by (-)erythrofluorocitrate. Proceedings of the National Academy of Sciences of the United States of America 74, 4942-4946.

LeE, F.-J. S., LIN, L.-W. \& Smith, J. A. (1989). Purification and characterization of an acetyl-CoA hydrolase from Saccharomyces cerevisiae. European Journal of Biochemistry 184, 21-28.

Maconochie, M. K., Connerton, I. F. \& Casselton, L. A. (1992). The acu- 1 gene of Coprinus cinereus as a regulatory gene required for induction of utilisation of enzymes. Molecular and General Genetics 234, 211-216.

McCullough, W. \& Roberts, C. F. (1974). The role of malic enzyme in Aspergillus nidulans. FEBS Letters 41, 238-242.

Marathe, S., Connerton, I. F. \& Fincham, J. R. S. (1990). Duplication-induced mutation of a new Neurospora gene required for acetate metabolism: properties of the mutant and predicted amino acid sequences of the protein product. Molecular and Cellular Biology 10, 2638-2644.

MunKRES, K. D. \& Richards, F. M. (1965). Genetic alterations of Neurospora malate dehydrogenase. Archives of Biochemistry and Biophysics 109, 457-465.

MunKRes, K. D., Giles, N. H. \& Case, M. E. (1965). Genetic control of Neurospora malate dehydrogenase and aspartate aminotransferase. Archives of Biochemistry and Biophysics 109, 397-403.

MunKRes, K. D., Benveniste, K., Gorski, J. \& Zuiches, C. A. (1970). Genetically induced subcellular mislocation of Neurospora mitochondrial malate dehydrogenase. Proceedings of the National Academy of Sciences of the United States of America 67, 263-270.

PERKINs, D. D. (1964). Multiple interchange stocks for linkage detection. Neurospora Newsletters 6, 22-23.

Peters, R. A. (1957). Mechanism of the toxicity of the active constituent of Dichapetalam cymosum and related compounds. Advances in Enzymology 18, 113-159.
RAO T. K. \& Debusk, A. G. (1977). An inducible acetate transport system in Neurospora crassa conidia. Biochimica et Biophysica Acta 470, 475-483.

Selker, E. U., Cambareri, E. B., Jensen, B. C. \& HaAck, K. R. (1987). Rearrangement of duplicated DNA in specialized cells of Neurospora. Cell 51, 741-752.

Schwitzguebel, J. P., Moller, I. M. \& Palmer, J. M. (1981). Changes in density of mitochondria and glyoxysomes from Neurospora crassa: a re-evaluation utilizing silica sol gradient centrifugation. Journal of General Microbiology 126, 289-295.

TAtUm, E. L., BarratT, R. W. \& CUTter, V. M. (1949). Chemical induction of colonial paramorphs in Neurospora and Syncephelastrum. Science 109, 509-511.

THOMAs, G. H. \& BAXTER, R. L. (1987). Analysis of mutational lesions of acetate metabolism in Neurospora crassa by ${ }^{13} \mathrm{C}$-nuclear magnetic resonance. Journal of Bacteriology 169, 359-366.

Thomas, G. H., Connerton, I. F. \& Fincham, J. R. S. (1988). Molecular cloning, identification and transcriptional analysis of genes involved in acetate utilization in Neurospora crassa. Molecular Microbiology 2, 599-606.

TURian, G. \& Matikian, N. (1966). Conidiation of Neurospora crassa. Nature, London 212, 1067-1078.

VoGEL, H. J. (1956). A convenient growth medium for Neurospora (medium N). Microbial Genetics Bulletin 13, 42-43.

Vousden, K. H. \& Casselton, L. A. (1983). Suppression of acetate mutants in Coprinus cinereus. II. Correlation of recessiveness and dosage with suppressed enzyme level. Current Genetics 7, 385-392.

WestergaARD, M. \& Mitchell, H. K. (1947). A synthetic medium favouring sexual reproduction. American Journal of Botany 34, 573 577. 